\title{
ПУТЕВОДИТЕЛЬ ПО АННАЛАМ СОЦИАЛЬНОЙ И ЭКОНОМИЧЕСКОЙ ИСТОРИИ ВОСТОЧНОЙ СИБИРИ*
}

В статье дается обзор пятого издания «Путеводителя по фондам Государственного архива Иркутской области», а также история становления архива и его развитие.

Ключевые слова: архив, Государственный архив Иркутской области, архивная служба.

E.V. ROSHUPKINA

\section{THE ANNALS OF SOCIAL AND ECONOMIC HISTORY OF EASTERN SIBERIA GUIDE}

The article reviews fifth edition of "State archives of the Irkutsk region Guidebook", deals with history and development of the Archive. service.

Keywords: archive, State archives of the Irkutsk region, archival

В 2017 г. вышел в свет «Путеводитель по фондам Государственного архива Иркутской области», составленный коллективом ученых-архивистов. Определяя цель издания «Путеводителя», авторы в предисловии

* Рецензия на «Путеводитель по фондам Государственного архива Иркутской области : в 2 ч. Ч. 1 : Досоветский период / сост. : Ю. П. Колмаков, Е. А. Луговская, Н. В. Чичкова, И. А. Чукавин, Н. В. Шашкова. - Иркутск : Изд-во «Оттиск», 2017. - 548 с. 
к изданию пишут: «В целях всестороннего использования архивных источников в интересах развития исторической науки, в ГАИО, как и в других государственных архивах, создана единая система научно-справочного аппарата. Обязательным элементом ее, наряду с описями и каталогом, является путеводитель по фондам архива. Основное назначение путеводителя - обеспечить общее ориентирование в составе хранящихся в архиве фондов и информационный поиск отдельных конкретных фондов. Он должен давать систематизированную и обобщенную информацию обо всех фондах архива, открытых для использования» (с. 9).

Новый «Путеводитель» по Государственному архиву Иркутской области (ГАИО) является пятым подобным изданием. Впервые работа над «Путеводителем» была проведена в 1948-1949 гг. коллективом ученых во главе с иркутским историком Ф.А. Кудрявцевым. В 1965 г. был издан второй вариант «Путеводителя», подготовленный сотрудниками архива при участии А.П. Мещерского и Ю.П. Колмакова. В 1975 г. вышел третий вариант «Путеводителя», который являлся дополненным и переработанным вариантом «Путеводителя» 1965 г. Наконец, в 1987 г. было опубликовано дополнение к «Путеводителю» 1975 г. Но, как отмечают авторы издания, «недостаток путеводителей 1975, 1987 гг., как и многих других путеводителей по региональным архивам, - их неполнота, наличие неаннотируемых фондов» (с. 10).

Пятый изданный «Путеводитель» по Государственному архиву Иркутской области стал самым полным справочником о составе и содержании фондов ГАИО. Его главной отличительной особенностью и преимуществом перед предыдущими изданиями стало количество представленных фондов и полнота их характеристик. «Путеводитель» состоит из двух частей: первая - «Фонды досоветского периода XVII в. - 1920 г.», вторая — «Фонды советского периода 1920-1991 гг.».

Издание новой версии «Путеводителя» по фондам ГАИО является не только значительным событием научной и культурной жизни Иркутской области, но и закономерным результатом формирования единого архивно-информационного пространства России. На рубеже XX-XXI вв., в связи с кардинальными преобразованиями в политическом и экономическом строе России, стала меняться проблематика гуманитарных исследований, в том числе в исторической науке. Иными словами, в условиях становления цивилизации нового типа, которую принято определять термином «информационное общество» возникла реальная потребность всестороннего осмысления и исследования истории. Удовлетворить данную потребность можно только на основе изучения объективных исторических источников. Неудивительно, что в этот период в России резко возрос общественный интерес к архивам и архивным документам. Использование ранее закрытой информации, хранящейся в документальном массиве архивов, положило начало процессу переос- 
мысления устоявшихся оценок тех или иных исторических фактов, событий, деятельности известных личностей.

В этих условиях одной из первостепенных задач стала модернизация деятельности архивов, связанной с формированием, сохранностью и использованием документального наследия как важной части национального и мирового историко-культурного достояния. Поэтому публикация нового «Путеводителя» по фондам ГАИО является, на наш взгляд, актуальным откликом на вызовы нового времени.

В настоящее время в России действует государственная архивная служба, которая представляет собой многоуровневую систему учреждений, в функции которых входит собирание, хранение и организация использования в научно-практических целях документов, относящихся к составу Архивного фонда Российской Федерации (АФ РФ). Она включает органы управления архивным делом субъектов РФ, а также находящиеся в их ведении государственные архивы республик, краев, областей и автономных округов. Государственный архив Иркутской области (ГАИО) является одним из структурных элементов этой системы. Сегодня ГАИО - это областное государственное казенное учреждение, подчиняющееся Архивному агентству Иркутской области. Иркутский архив, продолжая многовековые традиции, не только обеспечивает учет, хранение, комплектование, сохранность материалов, но и создает современный справочный аппарат, о чем свидетельствует публикация нового «Путеводителя».

Фонды ГАИО представляют собой исторически сложившуюся совокупность архивных документов за период с середины XVII в. до наших дней, которая является неотъемлемой частью Архивного фонда Российской Федерации. При этом уникальность фондов состоит в том, что они формировались постепенно в соответствии с изменениями в общественно-политической жизни страны и ее территориального устройства.

До появления понятия «архив» в России бытовали следующие названия: «хранила», «казна», «казенка», «бумажница», «присутственное место». В XVIII-XIX вв. возросший интерес к прошлому русского народа и российского государства привел к складыванию устойчивых комплексов исторических документов, а в общественном сознании понятие «архив» стало ассоциироваться с греческим словом «archaios» - древний.

В России в широкое употребление термин «архив» был введен «Генеральным регламентом», изданным 28 февраля 1720 г. В XVIII в. наиболее удачное определение термину «архив» дал В.Н. Татищев: «Архив... значит место такое, где государственные письма нужные яко тайные, тако и явные хранятся» [2, с. 9].

Следует учитывать, что в дореволюционной России как таковых государственных исторических архивов не было. Исторические архивы 
находились в ведении тех министерств или ведомств, чьи документы они хранили.

Историки И.Л. Маяковский и А.В. Чернов разделили историю архивного дела дореволюционного периода на три самостоятельных этапа.

Первый этап (с IX до конца XV столетия) - это период существования Древнерусского государства и период феодальной раздробленности. Характерная черта периода заключается в том, что документы хранились вместе с материальными ценностями.

Второй этап (конец XV - начало XVIII в.) хронологически соответствует периоду складывания и развития Русского централизованного государства. C конца XV в. документы стали хранить отдельно. Тогда же стали создаваться первые государственные учреждения - приказы. Это еще раз подтверждает тесную связь истории архивного дела и истории государственных учреждений. Письменные источники, потерявшие практическое значение, как правило, находились вместе с текущим делопроизводством.

Третий этап (начало XVIII в. - 1917 г.) характеризуется тем, что архивы превратились в самостоятельную структурную часть учреждения. Такие изменения были вызваны реорганизациями государственного аппарата, которые проводились правительством Петра I, в том числе созданием коллегий. Юридически отделение архивов от канцелярий было закреплено в «Генеральном регламенте» 1720 г. Именно в эти годы возникают первые исторические архивы. В работе архивов этого периода функции хранения уравновешивались функциями использования. Исторические архивы становятся лабораториями истории [4, с. 10-11].

И лишь после Октябрьской революции 1917 г. происходит оформление архивов в государственную отрасль управления во главе с генеральными дирекциями или национальными (центральными) архивами и связанными с ними местными архивохранилищами. Это период научного архивоведения. В России он начинается с момента издания Декрета СНК РСФСР от 1 июня 1918 г. «О реорганизации и централизации архивного дела в РСФСР». Декрет стал основой для создания государственной централизованной системы управления архивами.

История становления Государственного архива Иркутской области в целом отражает общие закономерности развития архивного дела в нашей стране. С одной стороны, он был неотъемлемой частью местного государственного аппарата, с другой стороны нес в себе все черты и традиции делопроизводственной и письменной культуры России.

Наиболее важным фактором, повлиявшим на состояние архивов, становление архивного дела, следовательно, на формирование документальной базы истории Иркутской губернии, на наш взгляд, является специфика социально-экономических процессов, свойственных стадии первичного освоения территории. Она характеризуется немногочислен- 
ным населением, его высокой миграционной подвижностью, смешанным этническим и конфессиональным составом. Все это нашло отражение в многократных реорганизациях административно-территориального устройства Восточной Сибири и, соответственно, в изменениях сети архивов и их статуса.

Официальной датой образования ГАИО является 29 марта 1941 г., когда на основании постановления СНК СССР существовавшие самостоятельно архивы Октябрьской революции и Исторический были объединены в Государственный архив Иркутской области. Сегодня Государственный архив Иркутской области является одним из богатейших архивов Сибири. В настоящий период в архиве находятся более 1 млн 46 тыс. единиц хранения, которые сосредоточены в 2690 фондах.

Наиболее ранние документы представлены в фонде Илимской воеводской канцелярии (1649-1774 гг.). Они, а также документы фондов Усть-Киренской воеводской канцелярии (1775-1785 гг.) и киренского нижнего земского суда (1782-1894 гг.) содержат ценные материалы по истории земледельческого освоения Ангаро-Илимо-Ленского района в XVII-XVIII вв.

Наиболее богаты фонды главного управления Восточной Сибири (1822-1887 гг.) и канцелярии иркутского генерал-губернатора (1887-1917 гг.). Отсюда можно почерпнуть важные материалы об экономическом, административно-политическом и культурном развитии Восточной Сибири, об экономических и культурных связях России с Китаем, Кореей и Монголией, о дружбе и сотрудничестве народов этих стран. Материалы упомянутых фондов показывают прогрессивную роль присоединения Сибири к русскому государству, благотворное влияние культуры русского народа на хозяйственную и духовную жизнь народов Восточной Сибири.

Документы фондов иркутского губернского правления (18391916 гг.), земской избы (1769-1800 гг.), городской думы (1789-1918 гг.), городской управы (1872-1917 гг.) и другие отражают историю Иркутска как культурно-экономического центра Восточной Сибири.

Фонды Иркутского губернского жандармского управления, районного охранного отделения, полицейских, судебных и тюремных учреждений дают представление о системе политического сыска, надзора за ссыльными, организации распределения на каторжные работы и поселение.

Обширный фактический материал по всем отраслям хозяйства и сферам человеческой деятельности содержится в фондах: финансовых, налоговых, кредитных органов, статистики, промышленности, учреждений землепользования и переселения.

Большой интерес представляют документы о культурном развитии Иркутской губернии, народного образования, высших и средних учебных заведений, органов здравоохранения. 
«Путеводитель по фондам Государственного архива Иркутской области. Часть 1: Досоветский период» состоит из предисловия, основной части и приложений. Как пишут авторы путеводителя: «основу дореволюционного комплекса документов архива составляют фронды Главного Управления Восточной Сибири, Канцелярии Иркутского генерал-губернатора, Иркутского губернского управления, органов городского самоуправления (городская дума и управа), в которых отражены процессы административных и политических преобразований, изменения структуры государственного аппарата, основные этапы и события экономического, социального и культурного развития Восточной Сибири» (с. 7).

«Путеводитель» удобен в использовании, так как структурирован по отраслевому принципу с учетом состава фрондов, хранящихся в архиве. Он включает в себя обзор фондов по 18 разделам, например, «Фонды местных органов государственной власти, управления и избирательных комиссий», «Фонды органов самоуправления», «Фонды органов суда, прокуратуры, нотариальных учреждений», «Фонды военных учреждений», «Фонды контрольных, финансово-налоговых, кредитных и страховых учреждений» и т.д. Разделы внутри систематизированы по принципу значимости фондообразователя и хронологии.

Характеристика каждого фонда в «Путеводителе» содержит название фонда, даты деятельности фондообразователя, справочные данные о фронде: объем фонда, хронологические рамки документов, количество описей, аннотацию.

Особую информационную ценность, на наш взгляд, представляют собой исторические справки, которые даются о каждом фондообразователе. Начинающие исследователи, обратившиеся к «Путеводителю», смогут получить интересные исторические сведения о том, что такое, например, воеводская канцелярия, уездные земские управы, волостные правления, земская изба, уездные полицейские управления и т.п.

Также, в помощь исследователям приложения «Путеводителя» содержат справки об административно-территориальном делении Восточной Сибири с XVII в. по 1920 г., список населенных мест Иркутской губернии в 1893 г., список руководителей Иркутской провинции, наместничества, Восточно-Сибирского (Иркутского) генерал-губернаторства, Иркутской губернии, городских голов.

Особый исторический колорит «Путеводителю» придают старые фотографии, с которых начинается каждый раздел издания. На них запечатлены виды старинного архитектурного облика Иркутска, предприятий дореволюционного времени, Транссибирской железной дороги, а также фото о наиболее ярких, значимых событиях политической, общественной и культурной жизни Иркутской губернии. 
Авторами издания проделана скрупулезная, титаническая работа, которая заслуживает особого уважения. Нет сомнения в том, что она найдет искреннюю благодарность в душе каждого, кто обратиться к «Путеводителю» за то, что архивные источники стали ближе и доступнее.

\section{Список использованной литературы и источников}

1. Курас С. Л. Государственный архив Иркутской области как уникальное хранилище документов о ссылке в Сибирь / С. Л. Курас // Известия Иркутского государственного университета. Серия История. - 2016. - Т. 16. - С. 214-219.

2. Старостин Е. В. Архивы России: Методологические аспекты архивоведческого знания : учеб.-метод. пособие / Е. В. Старостин. - М. : Русский мир, 2001. $-215 \mathrm{c}$.

3. Тагаров 3. Государственный архив Иркутской области / 3. Тагаров // Вопросы истории. - 1954. - № 7. - С. 183-184.

4. Цеменкова С. И. История архивов России с древнейших времен до начала XX века : учеб. пособие / С. И. Цеменкова ; науч. ред. Л. Н. Мазур. - Екатеринбург : Изд-во Урал. ун-та, 2015. - 155 с.

\section{Информация об авторе}

Рощупкина Елена Викторовна - кандидат экономических наук, доцент, кафедра истории и международных отношений, Байкальский государственный университет, 664003, г. Иркутск, ул. Ленина, 11; e-mail: history@bgu.ru

\section{Author}

Elena V. Roshupkina - PhD in Economics, Associate Professor, Department of History and International Relations, Baikal State University, 11 Lenin St., 664003, Irkutsk, Russia; e-mail: history@bgu.ru 